\title{
A DISCURSIVE ANALYSIS OF JAIR BOLSONARO: POPULIST AND ETHICAL (LACK OF) LIMITS THROUGH LANGUAGE
}

\author{
UMA ANÁLISE DISCURSIVA DE JAIR BOLSONARO: \\ DESLIMITES POPULISTAS E ÉTICOS PELA LINGUAGEM
}

\section{Ana Paula El-Jaick}

\begin{abstract}
This article is about the question of ethics in the studies of language and the intersection with philosophy. For this investigation, we chose as a case study the speech delivered by the then controversial Brazilian Federal Congressman Jair Bolsonaro in the vote for the impeachment of the (now former) president, Dilma Rousseff, in 2016. On that occasion, Bolsonaro, upon casting his vote, paid tribute to Colonel Carlos Alberto Brilhante Ustra, responsible for torture during the Brazilian civil-military dictatorship (1964-1985). Our purpose here is to discuss and (try) to formulate a discursive etbics, also calling into question whether some speech acts may be considered unacceptable. To develop our idea, we draw on the theoretical contribution the so-called second Wittgenstein's perspective of language, more specifically his idea of language as forms of life, put in dialogue with the position on ethics in the language put forwards by the professor of the University of Paris 13 MarieAnne Paveau in her book Language and Morality: An Etbics of Discursive Virtues.
\end{abstract}

Keywords: discursive ethics; L. Wittgenstein; forms of life.

\section{RESUMO}

Este artigo pretende investigar como questões éticas vêm sendo tratadas no âmbito dos estudos da linguagem. Para tal exame, escolhemos como estudo de caso o discurso proferido pelo então controverso Deputado Federal brasileiro Jair Bolsonaro quando votou favoravelmente pelo impeachment da (agora ex) presidenta Dilma Rousseff. Na ocasião, Bolsonaro, depois de dar seu voto, pagou tributo ao coronel Carlos Alberto Brilhante Ustra, notório responsável por torturas durante o período da ditadura civil-militar do Brasil (1964-1985). Nosso propósito aqui é discutir e (tentar) formular uma ética discursiva, também colocando em questão se alguns atos de fala podem ser considerados inaceitáveis. Para desenvolver nossa ideia, partimos da perspectiva de linguagem do assim chamado segundo Wittgenstein, mais especificamente de sua ideia de linguagem como formas de vida, posta em diálogo com a posição sobre ética na linguagem defendida pela professora da Universidade Paris 13 Marie-Anne Paveau em seu livro Linguagem e moral: uma ética das virtudes discursivas. Palavras-chave: Ética discursiva; L. Wittgenstein; Formas de vida.

\footnotetext{
* Universidade Federal de Juiz de Fora, UFJF, Juiz de Fora, MG, Brasil. anapaulaeljaick@gmail.com Orcid: https://orcid.org/0000-0002-2262-0206
} 


\section{INTRODUCTION}

This text investigates how language is thought about in the fields of philosophy and literature, considered as related areas of knowledge. I will mobilize L. Wittgenstein's pragmatic (and seminal) vision to dialogue with the discursive perspective of the Paris University 13 professor Marie-Anne Paveau (more specifically in her work Language and Morality: An Ethics of Discursive Virtues), with the aim of discussing the question of ethics in language studies. Thus, it is a reflection that dialogues between areas and, in the case of language studies, this paper is more invested in pragmatic conceptions of language. From this view, in which to imagine a language is to imagine a form of life (paraphrasing the philosopher $\mathrm{L}$. Wittgenstein, using the notion of form of life, which will be better understood later), I will look at the (sad) current political (and ethical) scenario in Brazil.

I undertake an ethical and discursive analysis, selecting more specifically a political discourse of a controversial Brazilian Federal Representative who doesn't hesitate to give misogynistic, racist, homophobic discourses. In fact, as will be seen, in the Brazilian Congress it is said that there are representatives of the "bullet, ox and Bible" groups. The "bullet" group is composed of politicians linked to the armaments industry (usually ex-police and military); the "ox" group is the ruralists, who defend the interests of the large landowners; and, finally, the "Bible" group is made up of evangelical representatives. The congressman in question, Jair Bolsonaro, was part of the first group, being himself a military reserve member. $\mathrm{He}$ was subsequently elected president.

Bolsonaro doesn't shy from giving misogynistic speeches, which have already appeared in international newspapers. An example of this was when he offended Representative Maria do Rosário of the Workers' Party (PT), saying: "I do not rape you because you do not deserve it." Also, complaints of racism are common for the representative. Once he attacked the quilombolas (descendants of black enslaved peoples), stating: "I went to a quilombo. The lightest Afro-descendant there weighed seven arrobas [arroba is a measure used to weigh cattle; one arroba equals $15 \mathrm{~kg}$ ). They don't do anything. I don't think they're useful anymore even to reproduce." In addition, he has made so many homophobic comments that a site has brought together "100 homophobic phrases from Jair Bolsonaro," in which one of them is: "I will not fight against it, nor discriminate, but if I see two men kissing in the street, I'll beat them." These discourses of hatred brought about the expected: they spread more hatred - both outrage against Bolsonaro and, also, imitation of him, reverberating violence. For purposes of analysis, I selected a speech in which the representative pays homage to a notorious torturer during the Brazilian military 
dictatorship. This discourse will be analyzed in conjunction with meta-discourses in response to it, as well as the profusion of texts that have emerged based on it.

That said, we will continue as follows. First, we will see this bipartition of the discourses contrary to and favorable to Bolsonaro in the contemporary media. In the following section, I will investigate how the ethical question is being addressed in language studies - in the meantime, I will also look at L. Wittgenstein's ordinary language perspective. The third section of this article examines more specifically Bolsonaro's discourse and the discourses to which it led. Finally, at the conclusion of this text, the possibility of a discursive etbics is raised.

The central question of this article may be embodied in the question: "Can one say anything?" (Because it's the central question of this research, this question will appear again several more times in this text.) As I will show later, it places ethics in the center of attention for a discursive study, showing that ethics and boundaries share something in common. Since I understand that examples are as valid as an analytical explanation, I will recall here the recent vote on the impeachment of the (now) former president of Brazil, Dilma Rousseff, in the National Congress, and then we will have illuminating definitions of this kind of limit between the speakable and the unspeakable. After all, we have had a rather rich display of discourses which, perhaps (and the objective here is to ascertain this), may be understood as "unacceptable" (see PAVEAU 2015 [2013]).

Paveau puts in question the relation between language and moral. That's why she begins her book with what she considers a moral and linguistic question and that one will be the center of her book, the already mentioned: "Can one say anything?" (PAVEAU 2015 [2013], p.18). The answer to this question is generally let to the philosophy, specially to the ethics. Paveau's claim (with which I agree) is that is is also a language matter.

This text suspects that one of those unacceptable discourses may have been the declaration of Federal Representative Jair Bolsonaro, a reserve military member who was admittedly a member of the so-called "bullet group" in the National Congress, in declaring his vote for the removal of the president "for the memory of Colonel Carlos Alberto Brilhante Ustra, the terror of Dilma Rousseff." ${ }^{\prime 1}$ The colonel, who was nostalgically remembered by the current Federal Representative of the Republic of Brazil, headed the Destacamento de Operações de InformaçãoCentro de Operações de Defesa Interna (DOI-Codi) [Information Operations Internal Defense Operations Center] and was, notoriously, responsible for torture

1.The Bolsonaro's vote can be seen at: https://www.youtube.com/watch? $=$ SroqvAT71o0 
during the Brazilian civil-military dictatorship (1964-1985). ${ }^{2}$ I understand this as an example of paying tribute to a flagrant torturer - and so much so that it is totally clear - to show how the intensification of Brazilians' political moods seems to have led to a limit of language on what can be said and what should remain a kind of "taboo".

The virtuous discourse is a question present in the history of the occidental thought since antiquity. For example, in Gorgias, Socrates argues that rhetoric and any other art should be done with a view to justice. Hence, his criticism against the sophists - who, according to Socrates, exercise a non-virtuous rhetoric, since they don't seek the truth:

I think that I am the only or almost the only Athenian living who practises the true art of politics; I am the only politician of my time. Now, seeing that when I speak my words are not uttered with any view of gaining favour, and that I look to what is best and not to what is most pleasant, having no mind to use those arts and graces which you recommend, I shall have nothing to say in the justice court. And you might argue with me, as I was arguing with Polus: -I shall be tried just as a physician would be tried in a court of little boys at the indictment of the cook. (PLATO, Gorgias, 521d-521e).

For Socrates, the retor must be a virtuous, just man - therefore, his speech must live up to his upright character. Virtuous speech should not aim at the public's delight; instead, the good rhetoric must seek the good.

To stay in a second example in order to show this attraction for virtuous speech throughout our Western history, we jump in time and see now in the contemporary linguistics and philosophy Austin's speech acts. Indeed, the speech acts depend on the speaker's sincerity so as not to be an abuse. This is how Austin, after listing his six rules for the success of speech acts, differentiates the first four from the last two:

\footnotetext{
If we offend against any of the former rules (A's or B's) - that is, if we, say, utter the formula incorrectly, or if, say, we ate not in a position to do the action because we are, say, married already, or it is the purser and not the captain who is conducting the ceremony, then the act in question, e.g. marrying, is not successfully performed at all, does not come off, is not achieved. Whereas in the two $\Gamma$ cases the act is achieved, although to achieve in it such circumstances, as when we are, say, insincere, is an abuse of the procedure. Thus, when I say 'I promise' and have no intention of keeping it, I have promised but... (AUSTIN, 1962[1955], p.15-16).
}

\footnotetext{
2.Brazil, unlike, for example, Argentina, did not judge the military members of the military dictatorship. Instead, Brazil opted for general amnesty. This makes it impossible to have an official file that proves the action of this military man. However, there are several reports of his victims, including expresident Dilma Roussef and others (Cf. https:/www1.folha.uol.com.br/poder/2019/08/ustra-eraum-monstro-que-me-torturava-com-choque-e-ria-diz-vitima-de-militar.shtml).
} 
Although, paradoxically, it does not appear in a totally comfortable way in language studies. An exception to the rule is found in the book Language and Morality - An Ethics of Discursive Virtues, by Paveau, in which the French professor discusses situations, whose main scenario was contemporary France, analogous to those of the Brazilian representative. These are cases like that of J.-M. Le Pen, who called the death of Jews in gas chambers a "question of detail" (an example cited and taken up by Paveau in her book: for example, in note 18 on p. 126); that of the retired French general, P. Aussaresses, who justified and legitimized the use of torture in the Algerian War (PAVEAU 2015, p.149-151); and that of G. Frêche, for whom "The Germans sent two million prisoners who had gone on holiday to take care of the Gretchen, while their husbands were suffering on the Russian front." (PAVEAU 2015, p.151-152)

In the face of discursive events such as these, Paveau formulated the question that guided her work - and also this analysis, because, even before reading her book, I had already asked myself this same question: "Can one say anything?" To try to answer this question, Paveau seeks to explicitly establish relationships between ethics and language. She proposes a philosopby of discourse, that is, her own discursive theory from a philosophical point of view. ${ }^{3}$

In this work - as in others - I am in solidarity with Paveau's purpose. Understanding that these "disciplinary boundaries," as Sophie Moirand puts it (also in quotes) in the beautiful preface to the French colleague's work, are imaginary lines that should not subordinate our intellectual thinking, but rather it is intellectual thinking that must tread the paths deemed necessary to develop knowledge, I propose to analyze the discourse of Federal Representative Jair Bolsonaro in the intersection between linguistics and philosophy.

\section{FOR AN ETHICAL THEORY OF DISCOURSE}

To speak of ethics in language is always a thorny question, since, so to speak, the category more easily seen as a lack of ethics in discourse, the lie, is not characterized by some discursive mark. In this way, this is perhaps the

\footnotetext{
3.As Sophie Moirand reminds us in her excellent preface to Paveau's work, this quest is not at all foreign to the field of discourse analysis (and I would add: nor in linguistics itself), since Althusser and Foucault inspired ideas for a theorizing of discourse (MOIRAND apud PAVEAU 2015, p.11-15).

4.Here I would like to clarify that I share the Grupo de Pesquisa TRAÇO [TRAÇO Research Group] with five other professors-researchers from Brazilian institutions who, like myself, postulate the relaxation of the boundaries between linguistic, literary and philosophical studies. I mention some of the group's work by way of illustration: EL-JAICK, 2014, 2015; MARTINS, 2015a, 2015b.
} 
main motive - certainly one of the motives - for linguists to avoid the task of putting ethics in language studies.

As an exception to the rule, it is worth remembering one of the necessary conditions imposed by J. L. Austin, in formulating his Theory of Speech Acts, to have happy speech acts: sincerity. According to Austin, if the speaker's intention is not mirrored in his speech act, it will be empty - the lack of sincerity is an abuse in language. However, it is easy to find counter-examples that the lack of sincerity in the locutionary act does not exempt it from producing effects: a priest may have lost his faith, but continue to exercise his ecclesiastical activities, for example. Therefore, when this unbelieving priest utters the ritualized, conventionalized expressions in an adequate situation and in a complete way, he can create another reality, such as marrying two people. That is: even though insincere, the speech act of the priest had, as a consequence, the perlocutionary act of uniting two persons in matrimony.

Another attempt to consider ethics in language studies was undertaken by $\mathrm{P}$. Grice. After all, his well-known Principle of Cooperation obeys an ethical maxim, the maxim of quality, whose supermaxim is: "Make a contribution that is real."

These and other examples appear in Paveau's rich review in her book, showing how the relationship between language and ethics appears, as Paveau puts it, "from Aristotle to Austin" (PAVEAU 2015, p. 59). Thus, a "language morality" has already been proposed by Bernard Gardin, at least. For Paveau, Gardin is the one who actually made proposals for articulating language and morality - in formulating the expression moral linguists, he was practically the only linguist to use the term "moral" in linguistic literature, defining the objects for the "linguistic subject":

\footnotetext{
What is the substance of language that is problematized, that is, assumed by the subject? It is, of course, the whole zone subject to variations, at a given moment and under certain circumstances - a zone which may vary, and such variations show the elasticity of what is sometimes called the "hard core" of the tongue. More simply, what does the subject pay attention to when speaking or writing, what are the non-spontaneous zones of language in which subjects reflect, keep watch, modify their behaviors, form themselves? Linguistic behavior is a vast and non-homogenous set in the eyes of the speaker, containing sensitive zones and neutral zones. (GARDIN 1985 apud PAVEAU 2015, p.98).
}

Paveau, however, criticizes Gardin for considering that he does not explore the moral dimension as such. According to Paveau, several elements are missing in Gardin's analysis: a moral philosophy, a conception of the articulation between morality and language, an epistemology and a psychology.

Besides Bernard Gandin, a "morality of language" has also been proposed by the aforementioned Sophie Moirand, who wrote the preface of Language and 
Morality. It is called the "ethics of responsibility in language", which is the fact that subjects occupying certain positions in a given society should be responsible for the effects of their speech acts.

Paveau, on the other hand, formulates a discursive ethic, suggesting that linguistics escapes from linguistic/extralinguistic binarism, "proposing an integrative treatment of the production of utterances" (PAVEAU 2015, p. 187). Her proposition deals with the question in terms of continuum between the internal production of the utterances (that is, "in the head" of the speaker) and the actual verbal production in external environments (PAVEAU 2015, p. 191-192). Paveau thus incorporates the notion of environment into her theory:

\footnotetext{
While the theory of discourse used by M. Pêcheux and his collaborators takes into account the social, political and historical dimensions (the meaning of "socio-historical" in the expression "socio-historical conditions of production"), the environment as conceived by philosophy of the discourse to which I refer, considers all the data, taking into account the social, political and historical, as well as the cultural, aesthetic, the biological and, therefore, the ethical. (PAVEAU 2015, p. 356).
}

One of Paveau's most important points for this article is her exploration of what I considered a "methodology" for this kind of discursive analysis. It is as a fixation of a methodology that I read the necessary elements established by Paveau for an analysis of discursive ethics: to have "a conception of morality (a moral philosophy), a conception of the articulation between morality and language, an epistemology and, undoubtedly, a psychology." (PAVEAU 2015, p. 100).

I will carry out this analysis methodology prescribed by Paveau, basing it on the philosophy of Wittgensteinian language. I argue that my proposal is not a parasite of Paveau's own project. So, as I said in the first paragraph of the Introduction, in this article I intend to develop, albeit briefly, the possibility of constructing - or of recognizing - an ethical criterion of discourse, having as theoretical presupposition one of the most influential parts of the so-called ordinary/common language philosophy: the language perspective of the second Wittgenstein.

\subsection{Ethics and philosophy of ordinary Wittgensteinian language}

As is well known, critics and interpreters often divide Wittgenstein's trajectory into at least two moments. According to D. Marcondes (1994, p.224), the most explicit rupture between the first and second Wittgenstein is precisely in his conception of language. In fact, not only does his perspective on language change, but such a change takes place from one pole to the other: from a search for a mathematically calculable language to the recognition that there is no calculation 
capable of reducing the heterogeneity of language. As it is the philosopher's second moment that is more of interest here, I will treat the first one in summary form, with the objective of then making a counterpoint with the change in his thinking in relation to language. I think it important to address the first phase of his thought, even if rather briefly, inasmuch as Wittgenstein himself believed that his understanding was necessary for a better understanding of his posthumous work, Philosophical Investigations ${ }^{5}$, most representative of his thinking in his second phase. In the words of the author in his foreword to this work, he tells us, referring to his earlier work:

it seemed to me that I needed to publish those old and new thoughts together, for they could only be truly understood by their opposition to my old way of thinking, having it as a backdrop.

The so-called first Wittgenstein is the author of Tractatus Logico-Pbilosopbicus (TLP), his only published book during his lifetime. The considerations about language in the TLP are subordinate to his interest in other themes, especially "the nature of logic, the purpose of philosophy and the place of the self" (GLOCK 1998, p.356).

The aim of the first Wittgenstein is to understand the relation between language and reality through logic (MARCONDES 1994, p.220). With regard to reality, to the ontological importance of the Wittgensteinian perspective in this first moment, it is useful here to consider the following celebrated passage:

The facts in logical space are the world (TLP, 1.13).

The philosopher formulates a theory in which there is a logical space that encompasses the total set of logical possibilities, that is, the set of all logically possible states of affairs (GLOCK 1998, p.136). Hence, logical space, by definition, has no exterior, since we could not even conceive of something that was not within the possibilities of updating - like a circle-square, to cite a well-known example. The world would be within the logical space, as the set of possibilities which actually exist.

Wittgenstein then proposes a version of linguistic foundationalism: the view that language should mirror the essence of the world. Thus, captured by a logical view of language, it attaches itself to an essentialist conception - of both language and reality. Language describes reality - it is a mirror image of the world - because it is governed by a logical syntax, an underlying system of rules for the use of signs (GLOCK 1998, p.336). The idea of an isomorphism between language and reality is, in fact, one of the

5. Henceforth PI. 
fundamental presuppositions of the Tractatus (see GLOCK 1998, SANTOS 1996, MARCONDES 1994). In Wittgenstein's own words:

What every figuration, whatever its form, must have in common with reality to be able to somehow - correctly or falsely - see it as the logical form, that is, the form of reality (TLP, 2.18).

Everyday language would be on the surface -- underlying it there would be an essential logic. Wittgenstein starts from the idea (also found in Frege and Russell) that the grammatical and logical forms of language do not necessarily coincide. The essence behind ordinary language would be unique and could be explained through an analysis of language and the world that revealed its structure, that is, through a description of what they have in common. That is, to arrive at that underlying language, there would be a calculation to be made and that calculation would be unique and uniform, discovered by logical analysis. Logical analysis, in turn, must show two things: that empirical propositions have meaning; and that the metaphysical propositions are absurd, since they transgress logical syntax (GLOCK 1998, p.48) - which causes Wittgenstein to end his book with the famous phrase:

Whereof one cannot speak, thereof one must be silent. (TLP, 7).

From this we can conclude that for the Wittgenstein of Tractatus, the relation between language and the world is: names mean objects or, in other words, meaning is the object they denote. Indeed, the central idea of the theory of the first Wittgenstein is that propositions are a form of representation (McGINN 1998, P.33). Since propositions appear to be states of things which actually take place or not (glock, 1998, p.61-3), Wittgenstein states that they must necessarily be bipolar: they may be true, and also may be false, according to whether they agree or disagree with the facts of the world. Language is not autonomous, since it must mirror the essential nature of reality.

After abandoning the conception of logical language of what became known as the first phase of his thinking, Wittgenstein formulates his well-known idea of language as game. If, in Tractatus Wittgenstein conceives of language as an isomorphic mirror of the world, in Philosopbical Investigations, the Austrian philosopher recognizes that he had chosen the recurrent dogmatic escape, that is, of not admitting a truth on the surface of language, of the world, and then duplicating the language, the world, and putting that truth into a hidden background, to be discovered by a logical analysis of language. Wittgenstein's Pbilosopbical Investigations, then, admits that the question he thought he had answered in Tractatus was already misleading: to want 
to understand whether language says the world, if it corresponds to thought, is already to imagine a metaphysical language, separated from the world and thought. Now Wittgenstein understands that meaningful thinking is language; and language does not exist apart from the world - just as the world is constituted by language. What there is, then, is an interrelationship in which language and world are mutually constituted. If Wittgenstein once argued for the need to make logical analyses to arrive at an understanding of language and the world, in Pbilosophical Investigations he admits that "we want to understand something that is already before our eyes" (PI § 89). Any duplication of the real, of language, is created, invented by the myopic view of logicians - as Wittgenstein acknowledges that the very author of Tractatus (PI § 23) also did this.

That said, from this pragmatic turn in the perspective of Wittgensteinian language, we come to understand that linguistic analysis must operate in ordinary, common language. The role of philosophy should be to enlighten, to clarify concepts, "for philosophical problems arise when language goes on vacation" (PI § 38, author's emphasis). Wittgenstein diagnoses a philosophers' mental cramp when they want to define a concept analytically outside their linguistic practices, which leads them to question what is "the" knowing, "the" being, as if language were on vacation, in some transcendence beyond its effective use:

When philosophers use a word - "knowing," "being," "object," "I," "proposition," "name" and try to apprehend the essence of the thing, one should always ask: is this word actually used in this way in the language in which it exists?

We have redirected the words of your metaphysical employment into your daily employment. (PI § 116).

Wittgenstein dialogues here with the Socratic idea that, in order to be able to use a word, one must be able to respond analytically to the question "What is X?" and this response must correspond to the very essence of $\mathrm{X}$. The philosopher in his philosophical investigations questions his imaginary interlocutor about what that defining essence of linguistic concepts would be. Wittgenstein, then, destroys an entire centennial construction of Western thought, which puts linguistic meaning into underlying, essential, metaphysical structures. ${ }^{6}$

Contrary to this tradition, Wittgenstein asserts in a provocative way in PI aphorism 371 that "Essence is expressed in grammar." That is to say that if one wants

\footnotetext{
6.In Philosopbical Investigations, Wittgenstein dialogues in his aphorisms with an imaginary interlocutor in whose features criticism - especially that which owes a debt to studies of his greatest commentators, Baker and Hacker - tends to recognize Socratic traits, hence to usually be referred to as "Wittgenstein's Socratic interlocutor."
} 
to know what a linguistic expression means, then the answer is not at the end of some calculation made about ordinary language it is not something to be sought in some deeper layer, hidden from linguistic practice. He builds another solution, now on shaky ground: the answer, as I have already said, lies in the clarification of how linguistic expression is ordinarily used.

Philosophy, according to Wittgenstein, shows nothing new - if there is no deep language beyond apparent language, then "philosophical discovery" is indeed already before our eyes. This has an impact on the understanding of linguistic meaning; it is not possible to define a concept in a priori form, that is, prior to its use. It is only in use that the linguistic sign breathes - since, outside of use, the linguistic sign is dead (PI § 432). Thus understanding the verbal language, to clarify the linguistic meaning, the criterion is in the very form of life [Lebensform] in which the language games are played.

Although the expression Lebensform appears only nine times throughout the Wittgensteinian work, an inversely proportional number is found of works (among books, theses and articles) dedicated to the theme. On this expression - not originally Wittgensteinian, but recurrent in German philosophy - I prefer not to finalize an interpretation, understanding rather that it should not even be finalized. This is because Wittgenstein reflects his own conception of language in his writing, that is, he does not provide analytical definitions for the expressions he uses in his explanation of how language functions. That is why I want to be consistent with Wittgensteinian philosophy and not propose a calculated definition of Lebensform. Moreover, I recognize in these commentators' various interpretations of a language conceived of as a form of life, the old recurrent problem in our Western philosophy: the fetish of fixing a single, fundamental, certain interpretation.

My proposal is, then, to reconcile two recurrent interpretations in Wittgenstein's secondary source, and to then understand plural forms of life, revealing a cultural pluralism - in this sense, language as life forms must reflect the spectrum of different human cultures - and also to understand the form of life in the singular, highlighting the human singularity - that is, language as (a) human life form. I argue that if Wittgenstein says that language is there, just like our own life, then language is all this together, paradoxically: a cultural relativism and a human universalism, which can best be formulated in the expression of Luiz Henrique Lopes dos Santos - a perspectivism without relativism (cf. SANTOS, 1996). ${ }^{7}$

In addition, I postulate that it cannot be considered a Wittgensteinian expression - in this case, form of life - as if detached from the rest of his writing. It

7.Soon I will cite this aphorism 559 Of Certainty, here paraphrased. 
is in this spirit that I intend to reconcile my interpretation of language as forms of life, like the idea developed by Wittgenstein, also in Pbilosophical Investigations, 1689, of family likeness.

It has been said (see note 4) that in Investigations..., Wittgenstein dialogues with a Socratic interlocutor. In these dialogues, the Austrian philosopher - one could say, maieuritically - unmasks the Augustinian conception of language (of the Socratic interlocutor), showing that it does not support closer examination. Thus, Wittgenstein impacts an ancient pillar of Western philosophy, as the question of identity is put to the test.

It is notorious that, in this history of linguistic ideas, we have numerous answers to the question of how one thing should be considered the same as another. With regard to language, we often see the conception of identity as fundamental to ensure the stability of linguistic meaning - the functioning of language itself. The Socratic answer to the problem of how we can use the same concept to refer to things which are different, though understood as equals, is a metaphysical answer; there would be a kind of ideal, primordial, essential super-concept, and the beings that mimic it would borrow its name. Thus the concept of "horse", for example, is stable, because there would be an essential borseness which all other horses mimic. So when I say "horse," you understand what I'm talking about, even though the idea that you have of horse may not be exactly the same as the one I have; it might be that I meant to refer to a painted horse, and you meant to refer to a black horse. Thus the stability of Socratic language is guaranteed in a metaphysical way - more than that: language only works depending on such metaphysics.

In the second moment of his philosophy, Wittgenstein follows the path of thinkers (like the sophists, and more recently we can cite F. Nietzsche, M. Bakhtin, G. Deleuze, J. Derrida, among others) who criticize such a Socratic postulate of an essential identity beyond appearances as something necessary for the very functioning of language. After all, if current language is every language that exists, then identity cannot be found in an unapparent depth. This dogmatic escape, as we have seen, Wittgenstein refuses in his mature formulations. Consequently, the idea of identity can only be conceived in the practice of language games played in ordinary life. Added to the view of Wittgensteinian family resemblance, we can say that if there is a recognizable similarity between the most diverse games that we practice, these approximations are made in the same way as between relatives of the same family, in which traces of kinship are recognized; they are not essential, but they show a certain familiar identity. Family similarity is the maximum one can find in Wittgenstein's mature philosophy to answer the philosophical question of identity. 
As a conclusion on the idea of language as a form of life in Wittgenstein, I advocate the idea that there can be no single interpretation for this expression if the philosopher himself recognized a lack of essential identity in the formulation of concepts. It is true that safeguarding a unique response would appease our scientific desire for well-defined results; however, Wittgenstein shows us that this is our desire - language games, however, do not respond to this logicist appeal:

You should keep in mind that the language game is, so to speak, unpredictable. I mean, it's not based on fundamentals. It is not reasonable (or unreasonable).

It's there - just like our lives. (WITTGENSTEIN, On Certainty, § 559).

Life is unpredictable - and so is language. A last foundation to which language should correspond is simply a dogmatic requirement to which language does not respond - nor does our life. This does not make language unreasonable, for that is not even a prerogative of language - it simply is. For this reason, I understand, Wittgenstein says: "To represent a language means to represent a form of life" (PI $\S 19$ ). And playing language games is a praxis done by life forms - cultural, human. And they are ways of life that regulate what can and cannot be said in language games.

In moral terms, the defining criterion of what would be ethical (and unethical), then, should be elucidated from the moment the criteria of use for such formulations in life forms are clarified. We have come to the point of investigating another concept that pervades our history of Western philosophical thought: the notion of criterion. My thesis is that, in Wittgenstein, this notion must also be understood pragmatically. ${ }^{8}$

A criterion is a standard - public, collective, intersubjective. Criteria govern the use of words in certain contexts, even though there is nothing that guarantees the success of a speech act (life, remember, is unpredictable). The recursive-ness of the criteria, then, only happens by its own recursion - within forms of life.

The criterion, in the Wittgensteinian perspective of language, not only individuates what a linguistic expression means in a game, but also establishes the importance that such term has in the forms of life. Put another way: the criterion gives identity to things while showing what (or how much) these things mean to the subjects within forms of life.

I bring up here the question of the criterion for making an analogy about what it is acceptable and unacceptable to say in a form of life. I mean that if ethical

8. For reasons largely developed by Paveau, the author justifies not distinguishing between ethics and morality. 
parameters are not essential, absolute, a priori, at the same time we follow rules and have socially established criteria that have absolute coercive value which is so absolute, as if they were essential.

I believe that my thesis does not go against what Paveau thinks. There are several passages in her book that inspired me to make such an affirmation. I highlight one: "Discourse seems to me to constitute human behavior in the most general sense, a human practice in the strong sense of the term" (PAVEAU 2015, p.51-52). If I understood Paveau's proposal (and so I agree with her), the human dimension would encompass not only individual judgments and emotions, but, contemplating this more general sense, also "cultural schemes, pre-discourses" (PAVEAU 2015, p.128).

\section{2. "BYE, DEAR": A CASE STUDY}

I return to Paveau's meticulous study, for I find there some useful remarks to develop a thesis on the ethical question in discourse. For example, if I want to state that there is a criterion in a form of life for what is acceptable/unacceptable to say, Paveau reminds me that moral indignation cannot be individual. The unacceptability has to have been recognized as such socially: "It is certainly possible to project this epistemic reasoning to the ethical value and to say that, in moral matters, the judgment of others is necessary for evaluation." (PAVEAU 2015, p.360).

Again, I see Paveau's postulation and the Wittgensteinian precept converge, for in Wittgenstein the criterion, the rule, can only be social, public. So also a certain ethical criterion cannot be defined from an "individual science" (PAVEAU 2015, p.360), since moral value is established in a sociocultural form of life. Consequently, as Paveau reminded me, it is that an individual evaluation is not enough to raise an ethical interdict. Hence one of her conclusions: "Outside a corpus, even reduced, of meta-discourses that demonstrate moral indignation that is not only mine, it doesn't seem that we can formulate the moral dimension of the utterances" (2015, p. 360).

I return, then, to my case study: we witnessed the Brazilian National Congress vote on the impeachment process of the (now former) president of Brazil, Dilma Rousseff. Several federal representatives make remarks that will soon be mocked by "petralbas"; they justify their votes to remove Rousseff from the presidency in a near-jargon "for my family, for God, for my children." 
In addition to this quasi-jargon - which, so recurrent, made the headlines even of the notorious anti-Dilma press, such as the newspaper $\mathrm{O} G l o b o^{9}-\mathrm{I}$ shall highlight, as explained in the introduction to this text, a specific speech made by an admittedly polemic figure: Federal Representative Jair Bolsonaro. Let us return to this recent past: April 17, 2016; scenario: National Congress; Federal Deputy Bolsonaro votes for the impeachment of the president:

On this day of glory for the Brazilian people, there is a name that will enter into history on this date, for the way he conducted the work in this house: congratulations, President Eduardo Cunha. They lost in '64. They lost now in 2016. For the family and the innocence of children in the classroom, which the PT never had. Against communism. For our freedom. Against the Folha de São Paulo. For the memory of Colonel Carlos Alberto Brilhante Ustra, the terror of Dilma Rousseff. For the exalted one of Caxias. For our Armed Forces. For Brazil, above all, and for God, above all - my vote is "Yes". ${ }^{10}$

Bolsonaro's vote for Dilma Rousseff's impeachment is rich in a rhetoric game that could be further investigated. Thus, its vocabulary of nationalist arms glory is notorious, for example. His opportunism is also shown in beginning by congratulating the President of Congress and leader of one of the best consolidated parties in Brazilian history, the PMDB - a party that, after the country's redemocratization, has always been, in one way or another, in power (example said that Dilma Rousseff's vice president was Michel Temer, also from the PMDB).

To say that "They lost in " 64 " means also not to be included in a "we" that is "communist" - wrongly considering the PT as a communist party. However, this type of discursive and compulsory alignment of linking the Workers' Party to communism has a rhetorical effect for those who still see communism as a threat to glorious Brazil. So much so that Bolsonaro immediately says literally: "Against communism". Thus, he stands as the defender of the Armed Forces and as a leader among those who want to remove the communes from power.

This positioning is also reflected in the "defense" by the family - and by a supposed irresponsibility of the PT to the innocence of Brazilian children, which also rescues a discursive memory that "communists eat little children". Therefore, not for free that Bolsonaro speaks "For our freedom", "for God" and "for the family": with our past still so recent, he evokes the discursive materiality March of the Family

\footnotetext{
9.O Globo is the most powerful journalism group in Brazil. Its political conservatism is known among Brazilians - to mention an example, we cite the work "A consumação do fato - Representações da primeira semana do 'Governo Lula' no telejornalismo da Rede Globo de Televisão", de Ana Carolina Rocha Pessoa Temer, who analyzed the (negative) coverage that this journalism network made of the first week of the Lula government.

10.Cf. note 1 .
} 
with God for Freedom - series of public manifestations in 1964 supporting the military that would protect Brazilians from the communist threat of that time.

Although all these analyzes can be done and deepened on Bolsonaro's speech, my point, as I explained in the introduction to this text, is that the homage paid by the representative to Ustra as "Dilma Rousseff's terror" raised the question that, coincidentally or not, was also the question that Paveau asked as the trigger of her work: "Can one say anything?"

Following Paveau's methodology, I sought to select a corpus of meta-discourses that would demonstrate a moral indignation because of Bolsonaro's discourse. In an ethnomethodological way, in a survey of news reports on the internet, one immediately notices the considerable number of articles that the case yielded.

The Instituto Vladimir Herzog [Vladimir Herzog Institute], for example, which uses, as a tribute, the name of the journalist who was a victim of the military dictatorship, stood up indignantly at the provocative act of the representative, asking that he be held criminally responsible. In a public note, the Institute understood Bolsonaro's act as an "defense of torture" and "incitement to crime in the House of Representatives", for which he should be criminally accused.

In addition, the representative was denounced to the International Criminal Court - located in The Hague, Netherlands - for a crime against humanity, a request made by the União Brasileira de Escritores (UBA) [Brazilian Union of Writers]. According to the indictment, the representative, apparently, defended torture.

The OAB-RJ [Rio de Janeiro Bar Association] also requested the annulment of the representative's mandate and the opening of criminal proceedings against him, both for "breach of parliamentary decorum." The penal sanction is requested for "defense of crime" based on article 287 of the Criminal Code, which, under the title "Crime against public peace", considers "incitement to crime": "To publicly defend a criminal fact or author of a crime: Penalty - detention, from 3 (three) to 6 (six) months, or fine" (BRAZIL, 1998). The president of OAB-RJ, Felipe Santa Cruz, son of Fernando Santa Cruz, an activist in the student movement and whose disappearance in 1974 is attributed to the military, understands that parliamentary immunity cannot be alleged to allow criminal attitudes. The lawyer does a questioning which is congruent with our reflection: "Can a representative defend crime from the height of the Congressional rostrum?" (cf. CONSULTOR JURÍDICO, 2016). That is, in addition to the question "can one say anything?", there is another question: can a representative of the National Congress use his place in the institution to pay homage to the "only torturer of the dictatorship 
officially considered so by the judiciary", as the press itself that (mostly) supported the impeachment stressed (EXTRA, 2016)?

So, this prerequisite imposed by Paveau is checked off - and many other indignant discourses could be added to that corpus, which is not at all small. However, there is still a nervous spot that concerns me. Paveau calls "discursive virtue" the formulation by criteria that define the moral acceptability of a discourse. These criteria must take into account the epoch in which the discourse occurs, the place, the society - that is, expected requirements for a theory that is based on a pragmatic view of language. Here again, I propose to understand Paveau's conception of discursive virtue in the light of the Wittgensteinian idea of form of life.

In both cases, the criterion for defining whether a given discourse is acceptable or not is governed by intersubjective, social rules. At the same time, Paveau speaks of a certain objectivity to construct this criterion of etbicality. I find this a fragile point in her theory - although he acknowledges that it would be "preferable" if it were even possible to establish an objective criterion for unacceptable discourses. After all, when we loosen the "rigor" that objectivity (for example, in the field of law) could achieve, we run the risk of falling into a kind of "bolsonarism", so to speak.

I mean to say that if all we can have is an intersubjective, social criterion, those who offer discourses we consider unacceptable may incriminate us, claiming that our discourse is unacceptable (after all, it is, but only to them).

This is the point that "concerns" me, and I believe it is the greatest challenge to face in proposing a discursive ethic, that is: the truth is that we deal with the ethical question by tipping the scale of ethics in our favor. In a movement that eschews a metaphysical ethic which, in the end and without giving it up, we end up prescribing, we consider some discourse unacceptable because, obviously, defending a torturer is unethical - and this "obviously" hides a premise that we ourselves do not admit, but that we subscribe to: that we are "on the side of good."

At this point, Paveau does not seem to deal completely with this "other side" - discourses indignant about our indignation. After all, if I transcribed some meta-discourses of moral indignation in relation to Bolsonaro's discourse (and, as I said, there is an expressive quantity of them), I omitted many others against them.

Taking advantage of the elasticity of the expression form of life, I say that if I am part of a form of life that considers Bolsonaro's speech unacceptable, I find myself with another form of life that supports him, that votes for him, that even idolizes him. So far I had not mentioned them, but it is necessary to recognize: although Bolsonaro was indicted for his discourse, Colonel Ustra's page had 3,000 "likes" in 72 hours, and at least four pages on the internet were created to pay homage to the 
torturer. The recognition of this struggle does not make us retreat, but it makes us re-signify our own theory.

Paveau, after dealing with religious and legal norms, says that:

The social norms (politeness and language) and the sociopolitical norms (the politically correct, taboos, censorship) are much less explicit than religious and legal norms, because they belong at the same time to a corpus of normative texts and to implicit knowledge. However, these are really standards, since their transgression is liable to social condemnation, such as stigmatization or exclusion, or moral condemnation, such as judgment. (PAVEAU 2015, p.159).

These linguistic social norms, if they are vague because language itself is vague, to my mind have the great knot to formulate a discursive ethics. A somewhat plausible hypothesis is that this question is more apparent because of our internet times. After all, if censorship has always been imposed by those who could impose it, in our day, with the internet, the struggle for this power - the struggle of classes, although this calls for a more in-depth examination (which I won't do in these brief lines), since we see an intertwining of classes, in which a certain middle class joins the less favored class at the same time that individuals from urban peripheries reproduce extremely elitist discourses - has a much more rapid and extremely intense repercussion. Ultimately, this power struggle (of classes) happens publicly; that is, the internet gave visibility to a duel that, in the past, was camouflaged, at best, in politically incorrect jokes ${ }^{11}$.

Paveau's formulation which, in terms of theory, guided this analysis, in the end, troubles me - less the formulation itself, which I consider to be beneficent, and more its (in)efficacy. I want to say, once again, that I distrust Paveau's confidence because of a norm. I conclude, without wishing to conclude, with an alert: that a "bolsonism" could be transformed into the norm. This means that if Bolsonaro is morally condemned for a form of life that considers ethical transgression its discourse, on the other hand, he is not exactly stigmatized, much less excluded (in fact, he was the most voted representative in the state of Rio de Janeiro, although it is noteworthy that the state representative elected with the largest number of votes, in the same election, was Marcelo Freixo, from the PSOL, a left-wing party). Indeed, as I review this article for publication, I receive news that the "suit against Bolsonaro is filed in the Ethics Board by 11 votes to 1 (see POLITICAL

11. I would like to warn the reader that, of course, the bibliography on the subject is vast. Here I chose to do this analysis via Paveau and Wittgenstein, but other works have been developed along the same lines of thought (Cf. Danillo Silva's book Quando dizer é violentar; Oriana Fulaneti's article "Por uma análise do discurso político: o caso Cristiane Brasil"). 
PRAGMATISM, 2016). ${ }^{12}$ What we are experiencing in Brazil seems to be exactly the norm problem: Bolsonaro has the power of a federal representative. In a somber perspective, to imagine that today's representative may gain even more political power, what would be a condemnation for "stigmatization" in this case? With this, the proposal that Paveau considers acceptable, that of the implementation of a meta-ethical device $(2015$, p.128-129) - a proposal that seems strange to me in our times which are contrary to the meta-theories - is, in my view, restricted. After all, how to propose a meta-theory for such adaptable life forms?

Of course: this is the knot of the question. For example, in the series of rules, codes, and Neltices ${ }^{13}$ cited by Paveau, there is a site in which the idea of rules of good conduct (PAVEAU 2015, p.167) is revealed. Such rules, I understand, always reveal the same problem: to assume that ethics is an essential being (which it is not). The Second Life's Code of Nethical Conduct, for example, speaks of "reciprocal respect": "Behave with others in the same way you would like them to behave with you." (see PAVEAU 2015, p.169). One can recognize here an attempt to reformulate the well-known Kantian ethical imperative - as well as in other moments of this same site, one can catch some confidence in a universal (essential) ethics when it appeals to "humanistic values."

The question that guided this text was "can one say anything?". In this semblance of conclusion, it returns: "Are we in a time when anything can be said?" And this apparent total freedom, recalling the Kantian imperative, paradoxically, reveals a lack of ethics. So we go back, then, as if we were walking in circles - or, being more optimistic, in a spiral - to the idea of (multiple) forms of life; we want unitary humanistic values for a multicultural, plural society. We want to argue that certain statements raise a moral issue because they touch values in our society, such as respect for others, sincerity, tolerance" (PAVEAU 2015, p.186), but our society is heterogeneous.

The problem seems to be that the theory proposed by Paveau assumes that the one who enunciates non-virtuous discourses is part of a small group - he is the exception to the rule. At the same time, this may be the salvation in not falling into relativism: if Paveau is right and the general rule is ethically virtuous agents, then even the one who utters an unethical discourse will know that he is doing so, and so an ethical virtue persists even in that agent who says the unacceptable.

As a last issue, let us turn to the reality in the Bolsonaro case: as a sort of "counter-argument" in his defense, his disciples say that figures like Che Guevara

12. I thank my friend and colleague Glória França (UFMA/Unicamp/FAPESP) for sending the article. 13. Nética or netiquette: amalgam formed from network and etiquette. 
were also torturers. This corroborates an idea that ethical virtue persists, but at the same time we suffer as victims of our own postmodern epoch. After all, our deconstructionist theories of discourse have led us to an aporia: we have such flexible criteria that tend to disappear - in this case, there is a comparison between torturer and tortured, as was well expressed Mário Magalhães (2016). ${ }^{14}$ One hypothesis is that Paveau's theory shows the gap between what we would like the real to be and what the real actually is. After all, here we are in this aporia: like the insect from the poem "Aporo", by the Brazilian poet Carlos Drummond de Andrade, we dig, we dig, "without finding an escape." Like Drummond's insect, we are "in a blocked country."

\section{THE END - BY NOW}

In this article, I analyzed Jair Bolsonaro's speech when he voted for the impeachment of Dilma Rousseff. The question that guided this research was "Can one say anything?" since, as we have seen, the then deputy glorified a torturer in the Brazilian Congress. To this end, I mobilized Wittgenstein's language perspective in contrast to Marie-Anne Paveau's recent book, in which she tries to formulate an ethical linguistic theory.

My main idea is that we can analyze the discursive formations that are currently bipolarized, and in radically opposite fields, as different forms of life. These different forms of life agree and disagree in language - in speech, in this case, for or against Bolsonaro. In language, we see what has been commonly called bubbles to form: a culturally oriented form of life shares a bubble in such a way that doesn't adheres to the discourse of the opposite form of life, as it were an opposite form of life. I therefore defend the aporia that we live today of an incommunicability between forms of life, as if even the limits of language were reached.

I risk a final escape (although I cannot dig deeper on it now): humor. With tired legs, I envision an unblocking to be better developed in some future work in which one examines the kind of emptying which irony provokes in unacceptable speeches. An example of many: Rodrigo Constantino, Brazilian economist and columnist who calls himself "a liberal without fear of polemics or the patrolling of

14. On the eve of closing this article, my student Márcia Andrade, whom I thank, e-mailed me a report that, due to lack of space (and time), I will not elaborate on in more detail here: the news that the Oxford Dictionary chose the expression "post-truth" to be the 2016 dictionary term of the year. The term used for the first time in 1992 by the Serbian-American playwright Steve Tesich was thus defined: an adjective "relating to or denoting circumstances in which objective facts are less influential in shaping public opinion than appeals to emotion and personal belief" (FABIO, 2016). 
the 'politically correct' left" (Constantino, blog), launches on the web a "Suggested list for boycott of artists, 'intellectuals' and 'petralha' journalists", at the top of which are musician, writer, and intellectual Chico Buarque, and writer Luis Fernando Veríssimo. Immediately a Facebook campaign emerges where social network ("petralha") users beg to get on the list - and thus figure alongside personalities who are not only very dear to the movement of fighting against reactionary policies but, mainly, are the greatest Brazilian artists and intellectuals. And here the wings manage to rehearse flight: that the mood be the anti-Euclidian orchid that forms beyond our aporetic spiral labyrinth.

\section{REFERENCES}

AUSTIN, J.L. (1962[1955]) How to do things with words. Oxford: Oxford University Press.

BAKER, GP, and HACKER, PMS. (1988). Wittgenstein, rules, grammar, and necessity. (An analytical commentary on the Philosophical Investigations; v.2). Oxford: Basil Blackwell.

BAKER, GP, and HACKER, PMS. (1984). An analytical commentary on Wittgenstein's Pbilosophical investigations. vol. 1. Oxford: Basil Blackwell.

BAKER, GP, and HACKER, PMS. (1980). Essays on the Philosophical Investigations - Wittgenstein - Meaning and understanding. Oxford: Basil Blackwell.

BRASIL. (1998) Código penal. Alterado pela Lei n. 9.777 em 26/12/1998. Available at: $<$ http://www.oas.org/juridico/mla/pt/bra/pt_bra-int-text-cp.pdf $>$. Accessed on: 14 nov. 2017.

CAVELL, S. (1996). The Cavell reader. Edited by Stephen Mulhall. Massachusetts, Oxford: Blackwell Publishers.

CONSTANTINO, R. Blog. Available at: < http://www.gazetadopovo.com.br/rodrigoconstantino/>. Acesso em: Nov. 14, 2017.

CONSULTOR JURÍDICO. (2016) "OAB-RJ pede cassação do mandato de Bolsonaro por homenagem a Ustra" Available at: <http://www.conjur.com.br/2016-abr-25/oab-rjcassacao-mandato-bolsonaro-homenagem-ustra >. Accessed on: Nov. 2, 2016.

EL-JAICK, A. P. G. (2014). Fogo, escada, purgante: a linguagem cética. Prometeus. Filosofia em Revista, v.7, p.63-81. 
EL-JAICK, A. P. G. (2015). Sexto Empírico e Saussure: um diálogo (de mudos?) entre o cético e o linguista. Breviário de Filosofia Pública, v.1, p.39-46.

EXTRA. "Bolsonaro é denunciado a tribunal penal internacional por discurso em votação do impeachment". Available at: <http://extra.globo.com/noticias/brasil/ bolsonaro-denunciado-tribunal-penal-internacional-por-discurso-em-votacao-doimpeachment-19185345.html>. Accessed on: Nov. 2, 2016

FÁBIO, A. C. (2016) O que é "pós-verdade", a palavra do ano segundo a Universidade de Oxford. Available at: <https://www.nexojornal.com.br/expresso/2016/11/16/Oque-\%C3\%A9-\%E2\%80\%98p\%C3\%B3s-verdade\%E2\%80\%99-a-palavra-do-anosegundo-a-Universidade-de-Oxford >. Accessed on: Nov. 24, 2016.

GLOCK, H-J. (1988). Dicionário Wittgenstein. Tradução: Helena Martins. Revisão técnica: Luiz Carlos Pereira. Rio de Janeiro: Jorge Zahar Ed.

MAGALHÃES, M. (2016) "Quem iguala torturador e torturado é conivente com Ustra e Bolsonaro". Uol Notícials, 20 abr. 2016. Available at: <"http:// blogdomariomagalhaes.blogosfera.uol.com.br/2016/04/20/quem-iguala-torturadore-torturado-e-conivente-com-ustra-e-bolsonaro/>. Accessed on: Nov. 6, 2016.

MARCONDES, D. (1994). "Wittgenstein: linguagem e realidade." In Caderno de pedagogia e cultura. Niterói.

MARTINS, H. F. (2015a). Words (mis)trusted. In: SCHUBACK, M. de S. C.; LANE, T. (Org.) Dis-orientations - Pbilosopby, Literature, and the Lost Grounds of Modernity, $1 \mathrm{ed}$. London: Rowman \& Lttlefiel, p.163-178.

MARTINS, H. F. (2015b). O idioma discretamente estrangeiro de Wittgenstein. In: ÁVILA, M.; STROPARO, S. (Org.). Poéticas do estranhamento. Curitiba: Arte e Letras, v.1, p. 100 .

McGINN, M. 1998. Routledge pbilosopby guidebook to Wittgenstein and the Philosopbical investigations. London and New York: Routledge.

PAVEAU, M-A. (2015). Linguagem e moral: uma ética das virtudes discursivas. Tradução: Ivone Benedetti. Campinas, SP: Editora da Unicamp.

PRAGMATISMO POLÍTICO. (2016) "Processo contra Bolsonaro é arquivado no Conselho de Ética por 11 votos a 1". Available at: < http://www.pragmatismopolitico. com.br/2016/11/processo-contra-bolsonaro-arquivado-conselho-de-etica.html $>$. Accessed on: Nov. 24, 2016. 
REDE BRASILATUAL. (2016) "Instituto Herzog manifesta indignação contra declaração de Bolsonaro". Disponível em: <http://www.redebrasilatual.com.br/politica/2016/04/ instituto-herzog-manifesta-indignacao-contra-declaracao-de-bolsonaro-6802. html>. Acesso em: Nov. 2, 2016

REVISTA LADO A. "100 frases homofóbicas de Jair Bolsonaro". Diponível em: < http:// revistaladoa.com.br/2016/03/noticias/100-frases-homofobicas-jair-bolsonaro $>$. Acesso em: Oct. 26, 2017.

SANTOS, L. H. L. dos. (1996). A harmonia essencial. In: NOVAES, A. A crise da razão. São Paulo: Companhia das Letras. 437-455.

SIQUEIRA, V. (2014) "Misoginia de Bolsonaro ganha destaque na mídia internacional". Colunas Tortas, 14 dez. 2014. Available at: <http://colunastortas.com.br/2014/12/14/ misoginia-de-bolsonaro-ganha-destaque-na-midia-internacional $/>$. Accessed on: Oct. 26, 2017.

ÚLTIMO SEGUNDO. (2016) "Juiz autoriza uso de técnicas de tortura em escola ocupada". Disponível em: <http://ultimosegundo.ig.com.br/brasil/2016-11-01/juiz.html>. Acesso em: Nov. 24, 2016.

VEJA. "Bolsonaro é acusado de racismo por frase em palestra na Hebraica". Disponível em: $<$ http://veja.abril.com.br/brasil/bolsonaro-e-acusado-de-racismo-por-frase-empalestra-na-hebraica/>. Accessed on: Oct. 26, 2017.

WITTGENSTEIN, L. (2001). Tractatus Logico-Pbilosopbicus. Tradução, apresentação e estudo introdutório de Luiz Henrique Lopes dos Santos; [Introdução de Bertrand Russell]. 3. ed. São Paulo: Editora da Universidade de São Paulo.

WITTGENSTEIN, L. (1975). Investigações filosóficas. Tradução: José Carlos Bruni. São Paulo: Abril Cultural. (Coleção Os Pensadores).

Recebido: $31 / 01 / 2020$

Aceito: 10/03/2020

Publicado: 13/04/2020 